\title{
Number of leaflets on rooting of lychee herbaceous cuttings
}

\section{Número de folíolos no enraizamento de estacas herbáceas de lichieira}

\author{
Ediane Conceição Alves ${ }^{I}$ João Emmanuel Ribeiro Guimarães ${ }^{I I}$ \\ Camila Kauffmann Becaro Franco ${ }^{\text {II }}$ Antonio Baldo Geraldo Martins ${ }^{\text {II }}$
}

- NOTE -

\section{ABSTRACT}

Lychee is one of the most popular exotic fruits in Brazil, and has both in natura and industrial potential. The objective of the present study was to evaluate the influence of the number of leaflets on lychee herbaceous cuttings treated with the indolebutyric acid $\left(1000 \mathrm{mg} L^{-1}\right)$. The experimental design was completely randomized, with 4 replications and 10 cuttings per experimental plot. Treatments consisted of cuttings with zero (0), one (1), two (2), three (3), and four (4) leaflets. After 180 days, the rooting and survival percentages and the number and length of roots were evaluated. The data were subjected to polynomial regression analysis. The increase in the number of leaflets was advantageus for all studied variables, with an increase in the survival, rooting of cuttings, and number and length of roots. The herbaceous cuttings of lychee tree are viable, provided that at least four leaflets remain in the herbaceous cutting.

Key words: leaflets, propagation, cutting, Litchi chinensis.

RESUMO

A lichia é umas das frutas exóticas mais populares no Brasil e apresenta potencial tanto in natura quanto industrial. $O$ objetivo deste estudo foi avaliar a influência do número de foliolos em estacas herbáceas de lichieira tratadas com ácido indolbutíico $\left(1000 \mathrm{mgL}^{-1}\right) . \quad O$ delineamento experimental foi inteiramente casualizado, com 4 repetições e 10 estacas por parcela experimental. Os tratamentos consistiram em estacas com zero (0), um (1), dois (2), três (3) e quatro (4) foliolos. Após 180 dias, as porcentagens de enraizamento e sobrevivencia,bem como o número e comprimento de raizes foram avaliados. Os dados foram submetidos à análise de regressão polinomial. O aumento no número de folíolos foi vantajoso para todas as variáveis avaliadas, com um correspondente aumento na sobrevivência, enraizamento das estacas e número e comprimento das raizes. A estaquia de ramos herbáceos da lichieira é viável, desde que pelo menos quatro foliolos sejam mantidos na estaca.

Palavras-chave: folíolos, propagação, estaquia, Litchi chinensis.
The lychee (Litchi chinensis) tree belongs to the Sapindaceae family, the same as native guaraná, and is among the most popular exotic fruit trees in Brazil (MARTINS et al., 2001; BASTOS et al., 2004). With a view to develop commercial orchards of the species, vegetative propagation is the most viable option, as it provides both uniformity among plants and anticipation of their productive phase (MARTINS et al., 2001; SASSO et al., 2010).

The cutting method has a great potential to replace or supplement the use of layering, as it has all the advantages of vegetative propagation. In addition, it allows obtaining a large number of individuals from one mother plant, in addition to a low production cost (CARVALHO et al., 2005).

In this method, the presence of leaves in the cuttings is a relevant factor to promote rooting. The leaves are sources of auxins and other cofactors that can be translocated to the cutting base and induce the formation of adventitious roots, as shown in blueberry trees (MARANGON \& BIASI, 2013). Conversely, the excessive presence of leaves or leaflets, can lead to dehydration of the material to be propagated and damage the rhizogenesis process, as occurred with peach tree cuttings (MINDÊLLO NETO, 2006).

Several studies have evaluated the effect of the indolebutyric acid (IBA) on rooting of stem cuttings in fruit tree species. There is an AIB concentration $\left(1000 \mathrm{mgL}^{-1}\right)$, which is among those

\footnotetext{
IDepartamento de Fitotecnia, Universidade Federal de Viçosa (UFV), 36570-900, Viçosa, MG, Brasil. E-mail: edianealveswork@hotmail.com. Corresponding author.

${ }^{I}$ Departamento de Produção Vegetal, Universidade Estadual Paulista (UNESP), Jaboticabal, SP, Brasil. 
already studied, that has allowed to obtain satisfactory responses in fruit tree species, such as the avocado (MINDÊLLO NETO et al., 2007) and jamboleiro trees (ALCANTARA et al., 2010).

Therefore, the objective of this study was to evaluate the influence of the number of leaflets in cloning, by cutting, of lychee tree herbaceous branches treated with IBA $\left(1000 \mathrm{mgL}^{-1}\right)$.

The experiment was conducted in an intermittent mist chamber in the area for production of fruit tree seedlings (Department of Plant Production, Faculdade de Ciências Agrárias e Veterinárias, FCAV, UNESP, campus of Jaboticabal, SP, Brazil) with sixyear-old herbaceous cuttings of the 'Bengal' lychee tree were used to perform the experiment. They belonged to the Active Germplasm Bank, Department of Plant Production, FCAV, UNESP) and were originated by air-layering.

Branches were collected in the morning and taken to the propagation area, in the fruit production area. Then, the cuttings were taken from the terminal portion of the branches (standard length: $c a .10 \mathrm{~cm}$ ), bevel cut at their base to increase the response area, and immersed $(5 \mathrm{~s})$ in an IBA alcoholic solution $\left(1000 \mathrm{mg} \mathrm{L}^{-1}\right)$. Treatments consisted of cuttings with zero (0), one (1), two (2), three (3), or four (4) leaflets.

Then the cuttings were placed in perforated

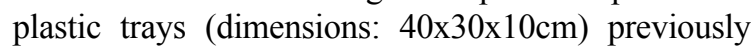
filled with expanded middle-texture vermiculite. They were maintained in a mist chamber (spraying: $15 \mathrm{~s}$; time interval: 45sec) under greenhouse conditions (shade: $50 \%$ ). After 180 days, the cuttings were evaluated for percent rates of survival and rooted cuttings, and number and average length of roots per cutting.

The completely randomized design was used in the experiment, with 5 treatments $(0,1,2,3$, or 4 leaflets present in the cutting), and each experiment was composed of 4 replicates and 10 cuttings per experimental plot. For data analysis, the rooting and survival percentages were calculated, and the number

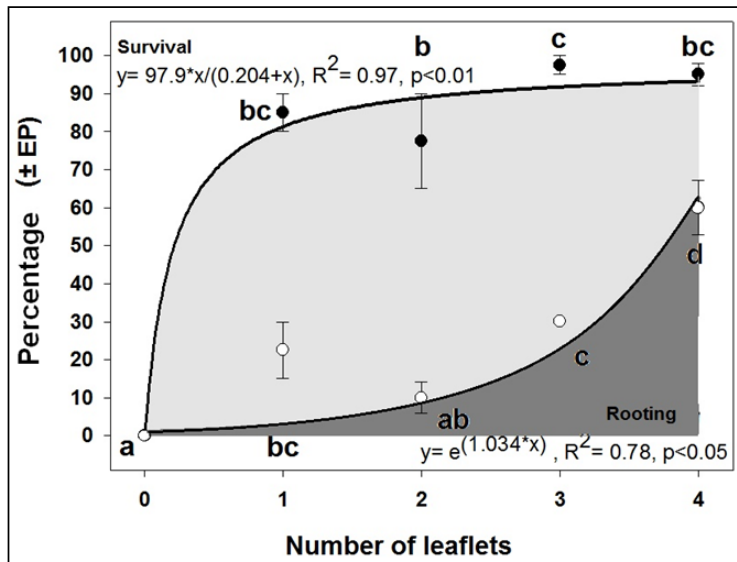

Figure 1 - Percentages of survival (A) and rooting in lychee cuttings as a function of the number of leaflets.

and length of roots were recorded. The rooting and survival percentages, and the number and length of roots were assessed by analysis of variance (ANOVA; $\alpha=0.05)$. The mean values for the studied variables were compared with the Fisher' spost hoc least significance difference (LSD; $\alpha=0.05)$ tests. Nonlinear regressions analyses were performed for all variables.

For survival percentage, it could be observed that total absence of leaflets in the cuttings results due their death, generated values equal to zero (Figure 1). Conversely, when only treatments in the presence of leaflets are compared, it becomes clear that presence of only one of them is sufficient for the mean values to be greater than $70 \%$ (Table 1). Possibly, this is due to the synthesis of phenolic compounds which are synthesized in the leaves. These compounds contribute to maintain the cutting survival, which may indicate a natural stimulus to rooting, acting as a facilitator of the rooting process in cuttings (FACHINELLO, 1995).

Regarding rooting of cuttings, a higher sensitivity to reduction in the number of leaflets is observed, and rooting is greatly affected in cuttings with one to three leaflets (Figure 1). However, the

Table 1 - Mean percentages and standard errors for survival, rooting, number, and length of roots as a function of the number of leaflets.

\begin{tabular}{|c|c|c|c|c|c|c|c|}
\hline \multirow{2}{*}{ Variables } & \multicolumn{4}{|c|}{-Number of leaflets----------------------------- } & \multirow{2}{*}{$\mathrm{F}$} & \multirow{2}{*}{$\mathrm{R} 2$} & \multirow{2}{*}{$\mathrm{P}$} \\
\hline & 1 & 2 & 3 & 4 & & & \\
\hline Survival & $85 \pm 5.0 \mathrm{ab}$ & $77.5 \pm 12.5 b$ & $97.5 \pm 2.5 a$ & $95 \pm 2.9 \mathrm{ab}$ & 41.86 & 0.92 & $<0.001$ \\
\hline Rooting & $22.5 \pm 7.5 b c$ & $10 \pm 4.1 \mathrm{c}$ & $30 \pm 0.01 b$ & $60 \pm 7.1 \mathrm{a}$ & 21.41 & 0.85 & $<0.001$ \\
\hline Number of roots & $0.5 \pm 0.18 b c$ & $0.2 \pm 0.11 \mathrm{c}$ & $0.8 \pm 0.17 b$ & $2.3 \pm 0.54 a$ & 3.39 & 0.26 & $<0.001$ \\
\hline Growth of roots & $0.75 \pm 0.30 \mathrm{bc}$ & $0.12 \pm 0.08 \mathrm{c}$ & $1.67 \pm 0.83 b$ & $3.14 \pm 0.62 \mathrm{a}$ & 3.18 & 0.25 & $<0.001$ \\
\hline
\end{tabular}

One-way ANOVA, with the Fisher's post hoc least significance difference test.

Mean values with the same letters are not significantly different from each other; $\mathrm{P}>0.05 ; \mathrm{R}^{2}$ : coefficient of determination.

Ciência Rural, v.46, n.6, jun, 2016. 
rooting potential with four leaflets demonstrated to be much more effective, reaching up to $60 \%$ of rooting, being also higher than other treatments (Table 1). For PAIVA \& GOMES (2011), the presence of leaves in cuttings becomes indispensable to some species, as they are natural sources of auxins, carbohydrates, and other factors. According to HARTMANN et al. (2002), they also greatly contribute to the success rooting of cuttings when these substances are accumulated in appropriate amounts in the regeneration zone.

As the number of leaflets increased, an increase was observed in the mean values for number and length of roots, which reached their maximum values (2.3 and 3.14, respectively) (Figures 2A and 2B). Presence of four leaflets provided significantly superior results in relation to cuttings with one, two, and three leaflets (Table 1).

This result can be explained by the fact that cuttings with a greater number of leaflets have a greater amount of auxins available. They potentiate the cuttings ability to emit roots and contributed to improve the quality of the root system (which did not occur in cuttings with fewer leaflets) when they are associated with exogenous application of IBA $\left(1000 \mathrm{mg} \mathrm{L}^{-1}\right)$.

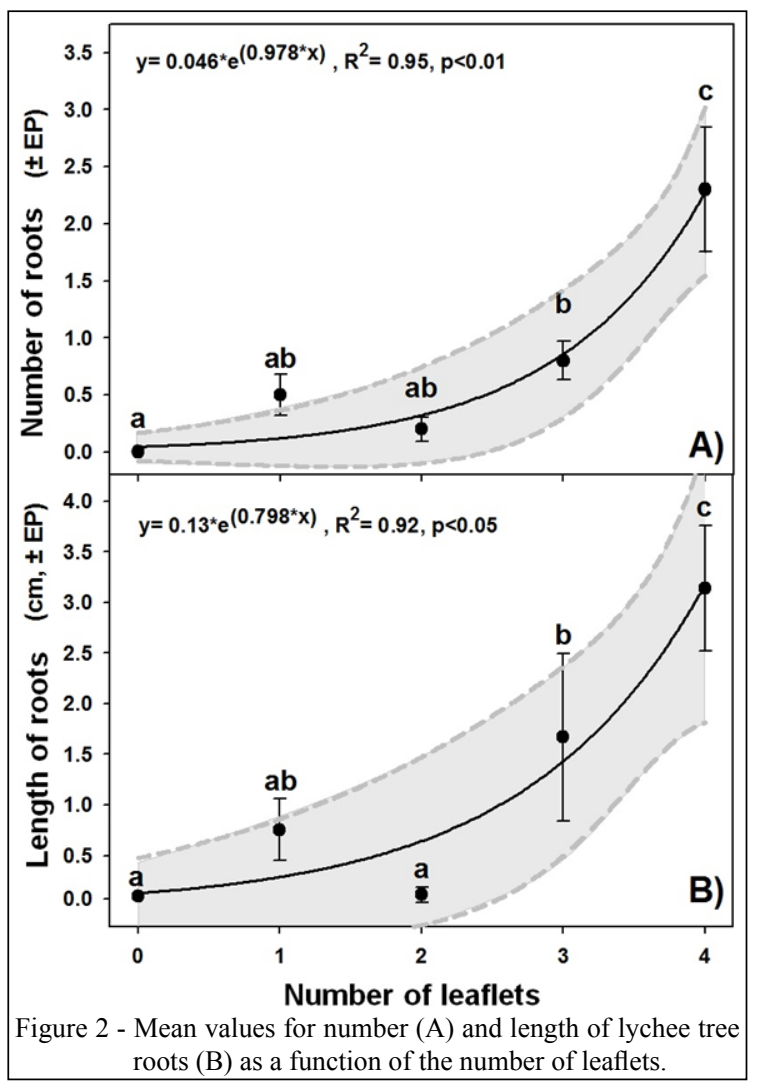

In general, it was observed that preservation of four leaflets was advantageous for all variables. According to PACHECO \& FRANCO (2008), such increase in all of them is probably linked to the presence of leaflets or leafs, which are sites of synthesis of various co factors involved in promoting rooting. For the lychee tree, however, it is important to emphasize that not only the presence of leaflets, but also keeping the maximum number of them is essential for the cuttings to reach the maximum rooting, with optimal quality of the root system.

\section{ACKNOWLEDGEMENTS}

The authors acknowledge the financial support from Coordenação de Aperfeiçoamento de Pessoal de Nível Superior(CAPES).

\section{REFERENCES}

ALCANTARA, G.B. et al. Effect of naphthalene acetic acid and indolebutyric acid on rooting of jambul [Syzygium cumini (L.) Skeels]. Revista Brasileira de Plantas Medicinais, Botucatu, v.12, n.3, p.317-321, 2010. Available from: <http://dx.doi.org/10.1590/ S1516-05722010000300009>. Accessed: Dec. 19, 2014. doi: 10.1590/ S1516-05722010000300009.

BASTOS, D.C. et al. A cultura da lichia. Piracicaba: DIBD/ESALQ, 2004. 23p. (Boletim técnico, 26).

CARVALHO, C.M. et al. Enraizamento de estacas semilenhosas de lichieira utilizando ácido indolbutírico. Revista Brasileira de Fruticultura, Jaboticabal, v.27, n.1, p.95-97, 2005. Available from: $\quad<\mathrm{http} / /$ www.scielo.br/scielo.php?script $=$ sci arttext\&pid=S0100-29452005000100026>. Accessed: Feb. 25, 2014. doi: 10.1590/S0100-29452005000100026.

FACHINELLO, J.C. et al. Propagação de plantas frutíferas de clima temperado. 2.ed. Pelotas: UFPel, 1995. 178p.

HARTMANN, H.T. et al. Plant propagation: principles and practices.7.ed. New Jersey: Prentice Hall, 2002.880p.

MARANGON, A.M.; BIASI, A.L. Estaquia de mirtilo nas estações do ano com ácido indolbutírico e aquecimento do substrato. Pesquisa agropecuária Brasileira, Brasília, v.48, n.1, p.25-32, 2013. Available from: <https://seer.sct.embrapa.br/index.php/pab/article/ view/12929/8965>. Accessed: Feb. 05, 2014. doi: 10.1590/S0100204X2013000100004.

MARTINS, A.B.G. et al. Lichieira (Litchi chinensis Sonn). Jaboticabal: Sociedade Brasileira de Fruticultura, 2001. 48p.

MINDÊLLO NETO, R.U. Estaquia herbácea de pessegueiro cv. 'Charme', em função de diferentes concentrações de ácido indolbutírico (AIB) e número de folhas. Revista Brasileira de Agrociência, Pelotas, v.12, n.1, p.27-29, 2006. Available from: $<$ http://periodicos.ufpel.edu.br/ojs2/index.php/CAST/article/ viewFile/1296/1080>. Accessed: Feb. 08, 2014.

MINDÊLLO NETO, R.U. et al. Enraizamento de estacas herbáceas do abacateiro 'Fuerte' com diferentes períodos de imersão em solução de ácido indolbutírico diferentes períodos de imersão em solução de 
ácido indolbutírico. Acta Scientiarun Agronomy, Maringá, v.29, n.3, p.387-390, 2007. Available from: $<$ http://periodicos.uem.br/ojs/index. php/ActaSciAgron/article/view/389/197>. Accessed: Feb. 05, 2014.

SASSO, S.A.Z. et al. Propagação de Jabuticabeira por estaquia. Revista Brasileira de Fruticultura, Jaboticabal, v.32, n.2, p.577583, 2010. Available: $<$ http://www.scielo.br/scielo.php?script $=$ sci arttext\&pid $=$ S0100 $>$. Accessed: Jan. 10, 2014. doi: 10.1590/ S0100-29452010005000054.
PACHECO,P.J.; FRANCO, H.T.E. Substratos e estacas com e sem folhas no enraizamento de Luehea divaricata Mart. Ciência Rural, Santa Maria, v.38, n.7, p.1900-1906, 2008. Available from: $<$ http://www.scielo.br/scielo.php?script=sci arttext\&pid $=$ S0103-84782008000700015 $>$. Accessed: Jan. 03, 2014. doi: 10.1590/S0103-84782008000700015.

PAIVA, H.N. de; GOMES, J.M. Propagação vegetativa de espécies florestais. 3.ed. Viçosa: UFV, 2011. 52p. 